Original Research Article

\title{
Evaluation of nephroprotective and nephrocurative activity of Aegle marmelos on albino rats using experimental model
}

\author{
Biswajit Kalita*, Monica Sharma, Pinki Vishwakarma, Shaily Bhatt, \\ Manish Saini, Kuldeep K. Saxena
}

Department of Pharmacology, L.L.R.M. Medical College, Meerut, Uttar Pradesh, India

Received: 24 January 2017

Revised: 19 March 2017

Accepted: 01 April 2017

*Correspondence to:

Dr. Biswajit Kalita,

Email: binabh008@gmail.com

Copyright: (C) the author(s), publisher and licensee Medip Academy. This is an openaccess article distributed under the terms of the Creative Commons Attribution NonCommercial License, which permits unrestricted noncommercial use, distribution, and reproduction in any medium, provided the original work is properly cited.

\begin{abstract}
Background: Renal diseases are common now days because of multiple nephrotoxic drugs use like aminoglycosides, analgesic etc. Many diseases like Diabetes and Hypertension also contributing to renal diseases. One of the mechanisms for nephrotoxicity is production of free radicals. The phytochemicals obtained from some plants are claimed to be useful in prevention of nephrotoxicity. One of the good sources of these phytochemicals is leaves of Aegle marmelos (Bael) which has antioxidant property that can be useful in nephroprotection. Hence this study was designed to investigate the nephroprotective as well as nephrocurative potential of Aegle marmelos.

Methods: Study was done on albino rats at LLRM Medical College as per CPCSEA guidelines after obtaining permission from IAEC. Nephrotoxicity was induced using injection gentamicin $(40 \mathrm{mg} / \mathrm{kg})$. The nephroprotective and nephrocurative effect was quantified using serum markers (BUN, Serum creatinine) and histopathological changes. Statistical analysis was done using ANOVA followed by post hoc dunnet's test.

Results: When compared with gentamicin induced nephrotoxicity, rats those who received aqueous extract of Aegle marmelos leaves showed significant $(\mathrm{p}<.001)$ reduction in nephrotoxicity.

Conclusions: It can be concluded from this study that leaves of Aegle marmelos possess siginificant nephroprotective activity.
\end{abstract}

Keywords: Aegle marmelos, Gentamicin, Nephrocurative, Nephroprotection

\section{INTRODUCTION}

Several xenobiotics like aminoglycosides, cephalosporins, anticancer drugs (cisplatin), amphotericin $\mathrm{B}$, analgesics etc exert their toxic effects by one or more pathogenic mechanisms that can produce nephrotoxicity. ${ }^{1}$ Nephrotoxicity is the third most common problem of the renal system with an estimated lifetime risk of $2-5 \%$ in Asia, 8-15\% in Europe and America and around 20\% in the Middle East. Some studies have reported that certain Indian medicinal plants containing phytochemicals show beneficial effects on kidney injury. ${ }^{2}$

Gentamicin, a typical aminoglycoside antibiotic is widely used in clinical practice for the treatment of life threatening gram-negative infections. Its chemical stability and rapid bactericidal action has made it a first- line drug in a variety of clinical conditions. This antibiotic generally causes drug-induced dose-dependent nephrotoxicity in $10-20 \%$ of therapeutic courses. ${ }^{3}$ Modern medicine lacks reliable nephroprotective drugs. In recent years, great efforts have been focused on traditional and herbal medicine for the treatment of ARF. ${ }^{4}$

Bael (Aegle marmelos), belongs to the family Rutacae, is a moderate sized, slender, aromatic tree used as ethnomedicines against various human ailments. ${ }^{5}$ Various phytoconstituents like flavonoids, alkaloids, sterols, tannins, phlobatannins and flavonoid glycosides have been isolated from the various parts of Aegle marmelos, which is responsible for its antioxidant and nephroprotective property. $^{6}$ It has documented antidiabetic, antimicrobial, anti-inflammatory, hepatoprotective, anticancer and antispermatogenic 
activity. ${ }^{7-12}$ Few inconclusive studies are available on the nephroprotective potential of Aegle marmelos. Hence, the present study was undertaken to authenticate its traditional use by using aqueous leaf extract of Aegle marmelos against gentamicin-induced nephrotoxicity in Albino Wistar rats.

\section{METHODS}

\section{Study design}

This was a prospective randomised experimental study conducted in department of Pharmacology, LLRM Medical college, Meerut (UP) during Nov 2016 to August 2016. The animals utilised in this study were wistar rats. Total duration of study was ten months. The study was commenced after getting approval from Institutional Animal Ethical Committee (Approval no. IAEC/2015/1 dated 14/515) of Lala Lajpat Rai Memorial Medical college, Meerut, India, registered under CPCSEA India (Registration No.819/04/ac/CPCSEA).

\section{Experimental animals}

Healthy Wistar rats (200-250g) of either sex were housed in CPCSEA approved animal house of LLRM medical college in groups. They were kept in polypropylene cages. Rats with subnormal renal functions were not included. The rats were maintained at a temperature of 25 $\pm 2^{\circ} \mathrm{C}$, relative humidity of 45 to $55 \%$ and under standard environmental conditions (12hrs light and $12 \mathrm{hrs}$ dark cycle). The animals had free access to food and water ad libitum. All the procedures were performed in accordance with the Institutional Animal Ethical Committee constituted as per the directions of the CPCSEA and it was carried out during official college hours. No pregnant female was included in the present study.

\section{Method of preparation of extract}

Aqueous extract of leaf of Aegle marmelos (bael) was prepared according to the method of National Institute of Health and Family Welfare (NIHFW), New Delhi, India. Fresh leaves were obtained and dried at $40^{\circ} \mathrm{C}$ for 48 hours followed by grinding in electrical grinder and the powder was separated. $200 \mathrm{~g}$ of leaf powder was mixed with 1.0 litre double distilled water and an aqueous extract was prepared. Extract was dried at reduced pressure and it was stored at $0-4{ }^{\circ} \mathrm{C}$. This preparation thus obtained was used for next 7 days of the study period. ${ }^{13}$

To induce nephrotoxicity, commercially available preparation of injectable gentamicin (Gentamicin manufactured by Alkem laboratories) was used.

Evaluation of nephroprotection was carried out for different study durations of 10,20,30 days. Rats were randomized by block randomisation method into three groups of 24 animals each. In each of the main groups, rats were randomly assigned to any of the three subgroups i.e. control (C), Gentamicin treated (GT) and Aegle marmelos treated (AMT) group of 6 rats each.

- Group-C: This group was administered normal saline $(2 \mathrm{ml} / 100 \mathrm{gm} /$ day) per oral once a day consecutively for test durations of 10,20 and 30 days.

- Group-GT: This group was administered normal saline $(2 \mathrm{ml} / 100 \mathrm{gm} /$ day $)$ per oral once a day for test durations. Injection Gentamicin $(40 \mathrm{mg} / \mathrm{kg})$ was given intraperitoneally (i.p.) once daily for last five days.

- Group AMT: This group was administered single morning dose of Aegle marmelos (500mg/kg/day) per oral for test durations and injection Gentamicin (40 $\mathrm{mg} / \mathrm{kg}$ i.p.) was given once daily for last five days.

In phase 1, rats were sacrificed 24 hours after the last dose of gentamicin injection (on $11^{\text {th }}, 21^{\text {st }}$ and $31^{\text {st }}$ day).

In Phase 2, the nephrocurative activity of A. marmelos was compared with the spontaneous reversal of Gentamicin nephrotoxicity. For this phase, 72 rats were randomized into two groups.

- Group 1: 36 rats were administered Gentamicin for 5 days in a dose of $40 \mathrm{mg} / \mathrm{kg}$ (i.p).

- Group 2: 36 rats were administered Gentamicin for 5 days in a dose of $40 \mathrm{mg} / \mathrm{kg}$ (i.p.). From fifth day onwards these rats were administered single morning dose of A. marmelos $(500 \mathrm{mg} / \mathrm{kg})$ per oral till the rats were sacrificed.

In phase 2 six rats from each group were sacrificed on $3^{\text {rd }}$, $5^{\text {th }}, 7^{\text {th }}, 10^{\text {th }}, 12^{\text {th }}$, and $14^{\text {th }}$ day after administration of last dose of gentamicin. After fasting for $24 \mathrm{hrs}$ with free access to drinking water, the rats were sacrificed under Ketamine $(75 \mathrm{mg} / \mathrm{kg})$ and Xylazine $(10 \mathrm{mg} / \mathrm{kg})$ anaesthesia which was given intraperitoneally. Blood samples were collected from abdominal aorta for performing biochemical tests and the kidneys were dissected out for histopathological study.

\section{Estimation of biochemical parameters}

The collected blood sample was centrifuged and separated serum was used for estimation of renal biochemical marker.

- $\quad$ Blood urea nitrogen (BUN)

- Serum creatinine

Blood urea nitrogen $(B U N)$

Serum urea was estimated by Liquimax urea reagent kit, spectrophotometrically (marketed by Avecon PVT. LTD.) from the serum. The kit utilises Marshall method. ${ }^{14}$ 


\section{Serum creatinine}

Serum creatinine was estimated spectrophotometrically by Auto Zyme Creatinine reagent kit (Marketed by Accurex Biomedical PVT. LTD.) from the serum. The kit utilises initial rate method using alkaline picrate. ${ }^{15}$

\section{Histopathological examination}

Rats from each group were sacrificed and the kidneys were dissected out for histopathological examination.The kidneys were washed with normal saline.A section of kidney was dissected, fixed in neutral buffered formalin $(10 \%)$ and then dehydrated with grades of ethanol $(70 \%$, $80 \%, 90 \%, 95 \%$ and $100 \%)$. Dehydration was followed by clearing the samples in xylene. It was then embedded in paraffin wax from which blocks were prepared and sections of $5 \mu \mathrm{m}$ thickness were prepared from the blocks using a microtome. ${ }^{16}$ Tissue sample were stained with Harris haematoxylin and eosin stain and subjected to histopathological examination. ${ }^{17}$

\section{Statistical analysis}

Mean \pm SEM was calculated for each group. The statistical analysis was done by using one way analysis variation (ANOVA) followed by post Hoc Test. p values <0.05 were considered as significant. $p$ Values were estimated by referring to appropriate tables. ${ }^{18}$

\section{RESULTS}

\section{Nephroprotective study (Phase-I)}

\section{Effect of Aegle marmelos on serum BUN}

In Aegle marmelos pre-treated groups (AMT) BUN levels ranged between $23.69 \pm 0.47$ to $40.75 \pm 0.45$ and were lower as compared to GT group, and reduction was significant ( $\mathrm{p}$ value $<0.001$ ) for all test durations of 10 , 20 , and 30 days.

Table 1: BUN levels in normal saline, Gentamicin and Aegle marmelos treated groups at different test durations $(n=6)$.

\begin{tabular}{|c|c|c|c|}
\hline \multirow{2}{*}{$\begin{array}{l}\text { Duration of } \\
\text { treatment } \\
\text { (days) }\end{array}$} & \multicolumn{3}{|c|}{ BUN(mg/dl) Mean \pm SEM } \\
\hline & $\mathbf{C}$ & GT & AMT \\
\hline 10 & $22.40 \pm 0.33$ & $63.17 \pm 0.44^{\alpha}$ & $40.75 \pm 045^{\varepsilon \lambda}$ \\
\hline 20 & $24.67 \pm 0.38$ & $62.80 \pm 0.67^{\beta}$ & $25.9 \pm 0.41^{\zeta \mu}$ \\
\hline 30 & $2330 \pm 0.46$ & $64.71 \pm 0.83^{\gamma}$ & $23.69 \pm 0.47^{\eta v}$ \\
\hline
\end{tabular}

$\alpha \mathrm{P}<0.001$ as compared to 10 days of control. $\beta \mathrm{P}<0.001$ as compared to 20 days of control. $\gamma \mathrm{P}<0.001$ as compared to 30 days of control. $\varepsilon \mathrm{P}<0.001$ as compared to 10 days of control. $\zeta \mathrm{P}$ $>0.05$ as compared to 20 days of control. $\eta \mathrm{P}>0.05$ as compared to 30 days of control. $\lambda \mathrm{P}<0.001$ as compared to 10 days of GT. $\mu \mathrm{P}<0.001$ as compared to 20 days of GT. $v \mathrm{P}<0.001$ as compared to 30 days of GT.
When compared to $\mathrm{C}$ group, the BUN level was significant at 10 days ( $\mathrm{p}$ value $<0.001$ ) and became close to $\mathrm{C}$ group ( $\mathrm{p}$ value $>0.05$ ) at 20 and 30 days pretreatment (Table 1).

There were significantly lower levels of BUN at 20 and 30 days treatment as compared to levels after 10 days with Aegle marmelos showing a time dependent limitation of BUN rise.

\section{Effect of Aegle marmelos on serum creatinine}

Table 2: Serum Creatinine normal saline, Gentamicin and Aegle marmelos treated groups at different test durations $(n=6)$.

\begin{tabular}{|c|c|c|c|}
\hline \multirow{2}{*}{$\begin{array}{l}\text { Duration of } \\
\text { treatment } \\
\text { (days) }\end{array}$} & \multicolumn{3}{|c|}{ S. Creatinine(md/dl) $($ Mean \pm SEM $)$} \\
\hline & $\mathbf{C}$ & GT & AMT \\
\hline 10 & $0.53 \pm 0.02$ & $1.97 \pm 0.03^{\alpha}$ & $0.96 \pm 0.04^{\varepsilon \lambda}$ \\
\hline 20 & $0.55 \pm 0.03$ & $1.72 \pm 0.05^{\beta}$ & $0.65 \pm 0.03^{\zeta \mu}$ \\
\hline 30 & $0.54 \pm 0.02$ & $1.67 \pm 0.04^{\gamma}$ & $0.51 \pm 0.05^{\eta v}$ \\
\hline
\end{tabular}

$\alpha \mathrm{P}<0.001$ as compared to 10 days of control. $\beta \mathrm{P}<0.001$ as compared to 20 days of control. $\gamma \mathrm{P}<0.001$ as compared to 30 days of control. $\varepsilon \mathrm{P}<0.001$ as compared to 10 days of control. $\zeta \mathrm{P}$ $>0.05$ as compared to 20 days of control. $\eta \mathrm{P}>0.05$ as compared to 30 days of control. $\lambda \mathrm{P}<0.001$ as compared to 10 days of GT. $\mu \mathrm{P}<0.001$ as compared to 20 days of GT. $v \mathrm{P}<0.001$ as compared to 30 days of GT.

In Aegle marmelos pre-treated groups (AMT) serum creatinine levels ranged between $0.51 \pm 0.023$ to $0.96 \pm 0.029$ and were lower as compared to GT group, and reduction was significant ( $\mathrm{p}$ value $<0.001$ ) for all test durations of 10, 20, and 30 days. When compared to $\mathrm{C}$ group, the serum creatinine level was significant at 10 days ( $\mathrm{p}$ value $<0.001$ ) and became near $\mathrm{C}$ group ( $\mathrm{p}$ value $>0.05$ ) at 20 and 30 days pre-treatment (Table 2).

The level of serum creatinine was significantly lower levels at 20 and 30 days treatment as compared to levels after 10 days with Aegle marmelos showing a time dependent limitation of serum creatinine rise.

\section{Nephrocurative study (phase-II)}

\section{Effect of Aegle marmelos on serum BUN}

The spontaneous reversal of BUN in group II took nearly 10-14 days and was not significantly different ( $\mathrm{p}$ value $>0.05$ ) compared to group I. The BUN level between group I (gentamicin $40 \mathrm{mg} / \mathrm{kg}$ i.p. for 5 days) and group II (Aegle marmelos $500 \mathrm{mg} / \mathrm{kg}$ oral for test duration) after 14 days was not significantly different ( $\mathrm{p}$ value $>0.05$ ) (Table 3).

\section{Effect of Aegle marmelos serum creatinine}

Serum creatinine in group II took nearly 10-14 days to became normal and was not significantly different ( $p$ 
value >0.05) as compared to spontaneous reversal of creatinine in group I. The serum creatinine levels of group I and II after 14 days were not significantly different ( $p$ value $>0.05$ ) (Table 4).

Table 3: BUN levels in Gentamicin only treated and Aegle marmelos at different test durations.

\begin{tabular}{|lll|}
$\begin{array}{l}\text { Subdivision of } \\
\text { groups } \\
\text { (days for which Aegle } \\
\text { marmelos was } \\
\text { administered) }\end{array}$ & $\begin{array}{l}\text { BUN (mg/dl) } \\
\text { (Mean } \pm \text { SEM) }\end{array}$ \\
\hline 3 & Group-1 & $\begin{array}{l}\text { Group-2 } \\
\text { (AMT) }\end{array}$ \\
\hline 5 & $69.78 \pm 0.49$ & $67.80 \pm 0.33^{\alpha}$ \\
\hline 7 & $66.16 \pm 0.51$ & $63.74 \pm 0.73^{\beta}$ \\
\hline 10 & $56.35 \pm 0.81$ & $52.90 \pm 0.48^{\gamma}$ \\
\hline 12 & $34.05 \pm 0.55$ & $32.66 \pm 0.30^{\delta}$ \\
\hline 14 & $26.53 \pm 0.47$ & $25.42 \pm 0.26^{\varepsilon}$ \\
\hline
\end{tabular}

${ }^{\alpha} \mathrm{P}>0.05$ as compared to 3 days of group $-1 .{ }^{\beta} \mathrm{P}>0.05$ as compared to 5 days of group-1. $\gamma \mathrm{P}>0.05$ as compared to 7 days of group-1. ${ }^{\delta} \mathrm{P}>0.05$ as compared to 10 days of group- $1 .{ }^{8} \mathrm{P}>0.05$ as compared to 12 days of group-1. ${ }^{\zeta} \mathrm{P}>0.05$ as compared to 14 days of group-1.

Table 4: Serum creatinine levels in Gentamicin only treated and Aegle marmelos at different test durations.

\begin{tabular}{|lll|}
$\begin{array}{l}\text { Subdivision of } \\
\text { groups } \\
\text { (days for which Aegle } \\
\text { marmelos was } \\
\text { administered) }\end{array}$ & $\begin{array}{l}\text { S. Creatinine (mg/dl) } \\
\text { (Mean } \pm \text { SEM) }\end{array}$ \\
\hline 3 & $\begin{array}{l}\text { Group-1 } \\
\text { (C) }\end{array}$ & $\begin{array}{l}\text { Group-2 } \\
\text { (AMT) }\end{array}$ \\
\hline 5 & $1.43 \pm 0.01$ & $1.19 \pm 0.03^{\alpha}$ \\
\hline 7 & $1.10 \pm 0.02$ & $1.06 \pm 0.02^{\beta}$ \\
\hline 10 & $0.91 \pm 0.02$ & $0.86 \pm 0.01^{\gamma}$ \\
\hline 12 & $0.79 \pm 0.01$ & $0.69 \pm 0.02^{\delta}$ \\
\hline 14 & $0.56 \pm 0.02$ & $0.56 \pm 0.02^{\varepsilon}$ \\
\hline
\end{tabular}

${ }^{\alpha} \mathrm{P}>0.05$ as compared to 3 days of group-1. $\beta \mathrm{P}>0.05$ as compared to 5 days of group-1. ${ }^{\gamma} \mathrm{P}>0.05$ as compared to 7 days of group-1. ${ }^{\delta} \mathrm{P}>0.05$ as compared to 10 days of group-1. ${ }^{\varepsilon} \mathrm{P}>0.05$ as compared to 12 days of group- 1 . ${ }^{\zeta} \mathrm{P}>0.05$ as compared to 14 days of group-1.

\section{Histopathological changes}

The histopathological sections of the rats of showed almost normal architecture of kidney after 10, 20 and 30 days of pre-treatment, as compared to GT at 10, 20 and 30 days group. Histopathological examination of the kidneys of the rats treated with Aegle marmelos revealed absence of inflammatory casts and minimal glomerular congestion. Thus, the nephroprotective effect was confirmed by the histopathological examination of the kidney, wherein the normal architecture of the cellular structure was restored with absence of inflammatory casts.
The spontaneous reversal of morphological changes in group II (Aegle marmelos $500 \mathrm{mg} / 100 \mathrm{gm}$ oral for test duration) took nearly 5 days and were not significantly different compared to the group I (gentamicin $40 \mathrm{mg} / \mathrm{kg}$ i.p. for 5 days).

\section{DISCUSSION}

Drug nephrotoxicity plays a major role in the high incidence and prevalence of acute renal failure in both hospitalized and non-hospitalized patients.

In a recent study it was found that between 5\% and $10 \%$ of acute renal failure recognized in such patients is caused, at least in part, by drugs. ${ }^{19}$ The types of kidney dysfunction that are induced by nephrotoxic drugs include acute tubular necrosis, glomerular and tubulointerstitial injury, haemodynamically mediated damage and obstructive nephropathy. ${ }^{20}$

In the present study, the preventive and curative potential of the Aegle marmelos was evaluated by using Nephrotoxicity induced by gentamicin model. There are three reasons to select this model in this study. Firstly the gentamicin nephrotoxicity is a major concern in clinical practice and accounts for nearly $10 \%$ of all cases of drug induced nephrotoxicity. ${ }^{21}$ Secondly, nephrotoxicity is rapidly induced in rats and presents with established morphological changes and biochemical markers. ${ }^{22}$ In addition to that gentamicin induced nephrotoxicity has spontaneous reversal potential within 20 days. ${ }^{23}$ Hence, it provides an opportunity to study the nephroprotective and nephrocurative properties of Aegle marmelos.

The standard parameters in preclinical and clinical trials for the detection and monitoring of renal function are serum creatinine and Blood urea nitrogen (BUN). These markers are still the gold standard in the minimal invasive clinical biochemical analysis. ${ }^{24}$

In present study pre-treatment with Aegle marmelos was found to be beneficial. The level of BUN and serum creatinine were significantly decreased in groups treated with these two drugs as compared to GT group. When compared with saline treated $\mathrm{C}$ group, the levels of BUN and serum creatinine were significantly raised on $10^{\text {th }}$ day. However, in group with 20 and 30 days of pretreatment, the levels of biomarkers were not significantly different from control (C) group. It can be inferred from these findings that plasma concentration of Aegle marmelos requires some time to reach a level where they can afford protection against renal tissue injury.

In phase II of the study, the nephrocurative activity of Aegle marmelos was studied by comparing it with spontaneous reversal of gentamicin nephrotoxicity. Though BUN and serum creatinine levels in Aegle marmelos treated groups were less than gentamicin alone treated group, the reduction was not significant $(\mathrm{p}>0.05)$ at all test durations i.e. $3^{\text {rd }}, 5^{\text {th }}, 7^{\text {th }}, 10^{\text {th }}, 12^{\text {th }}$ and $14^{\text {th }}$ day. 
The failure to provide nephrocurative activity can be attributed to the facts that gentamicin accumulation within the renal cells damages a significant number of cells beyond repair which might not take up the active ingredient of Aegle marmelos. ${ }^{25}$ Also, the curative effect was studied after administration of drugs for 14 days which may be less for these drugs since nephroprotective activity of this drug was best seen after 20 days.

\section{CONCLUSION}

From the present study, it can be concluded that Aegle marmelos has good nephroprotective property. Based on observations in present study and already proven health benefits in other ailments, it can be proposed that Aegle marmelos supplementation may provide a cushion from drug induced nephrotoxicity without significant harmful effects.

The present study need to be further evaluated by using alternative route of administration, increasing the test duration, with different doses and in a different species so that Aegle marmelos can be proven not only as nephroprotective but nephrocurative drug also.

\section{ACKNOWLEDGEMENTS}

Authors are thankful to Dr. Abhinav David (Lecturer), Miss Mani Goel (Lecturer, Department of Pharmacology), Dr Rajkumar Goel (Lecturer, Department of Pharmacology), L.L.R.M. Medical College, Meerut, U.P. for their cooperation and sincere helps in this study.

Funding: No funding sources Conflict of interest: None declared

Ethical approval: The study was approved by the Institutional Ethics Committee

\section{REFERENCES}

1. Naughton CA. Drug induced nephrotoxicity. Am Fem Physician. 2008;78(6):743-50.

2. Bhattacharjee SK. Hand Book of Medicinal Plants. $2^{\text {nd }}$ edition. Pointer Publishers Jaipur.1998;2:228.

3. Arshad A, Karan Ajay G, Khushboo B, Kale MK. Protective effect of methanolic leaf extract of Caesalpinia Bonduc (L.) on gentamicin-induced hepatotoxicity and nephrotoxicity in rats. IJPT. 2011;10:21-5.

4. Laxmi SM, Reddy UK, Sandhya Rani KS. A review of medicinal plants for nephroprotective activity. Asian J Pharmacol clin res. 2012;5(4):8-14.

5. Sharma GN, Dubey SK, Sharma P, Sati N. Medicinal values of Bael (Aegle marmelos) (L.) Corr.: a review. Int J Curr Pharmaceut Rev Res. 2011;1(3):12-22.

6. Maity P, Hansda D, Bandyopadhyay U, Mishra DK. Biological activities of crude extracts of chemical constituents of Bael, Aegle marmelos (L.) Corr. Indian J Experimen Biol. 2009;47:849-61.
7. Upadhya S, Shanbhag KK, Suneetha G, Naidu BM, Upadhya S. A study of hypoglycemic and antioxidant activity of Aegle marmelos in alloxan induced diabetic rats, Ind $\mathrm{J}$ Physiol Pharmacol. 2004;(48):476-80

8. Maheshwari VL, Joshi PV, Patil RH. In vitro anti diarrhoeal activity and toxicity profile of Aegle marmelos Correa ex. Roxb. dried fruit pulp. NPR. 2009;8(5):498-502.

9. Arul V, Miyazaki S, Dhananjayan R. Studies on the anti-inflammatory, antipyretic and analgesic properties of the leaves of Aegle marmelos Corr. J Ethnopharmacol. 2005;96(4):159-63.

10. Singanan V, Singanan M, Begum H. The hepatoprotective effect of bael leaves (Aegle marmelos) in alcohol induced liver injury in albino rats. Int J Sci Tech. 2007;2(2):83-92.

11. Latica V, Costa, L. Evaluation of anticancer potential used in Bangladeshi folk medicine. J. Ethnopharmacol. 2005;99(1):21-38.

12. Pramanik T, Sur TK, Pandit S, Bhattacharyya D. Effect of Aegle marmelos leaf on rat sperm motility: an in vitro study. Indian J Pharmacol. 2002;34:276-7.

13. Das KU, Maiti R, Jana D, Ghosh D. Effect of aqueous extract of leaf of Aegle marmelos on testicular activities in rats. IJPT. 2006;5:21-5.

14. Marshall EK. A new method for the determination of urea in blood. J Biol Chem. 1993;15:487-94.

15. Pardue HL. Kinetic aspects of analytical chemistry. Anal Chem Acta. 1989;216:69-107.

16. Mubarak M, Kazi J, Lanewala A, Hashmi S, Akhter F. Pathology of adolescent nephrotic syndrome: are adolescents different from young children? Nephrol Dial Transplant. 2012;27.

17. Clayden EC. Pratical section cutting and stainingpart-1, London:Churchill Livingstone. 1971;4:.69

18. Ghosh MN. Fundamentals of Experimental pharmacology. $6^{\text {th }}$ ed. Hilton and Company. 2008;4:235-37.

19. Porter GA, Palmer BF, Henrich WL. Clinical relevance, in clinical nephrotoxins: renal injury from drugs and chemicals. Kluwer Academic Publishers.2003;3:3-20.

20. Mehta RL, Pascual MT, Soroko S, Himmelfarb BR, Ikizler, TA, Paganini EP et al. Spectrum of acute renal failure in the intensive care unit: The PICARD experience. Kidney Int. 2004;66:1613-21.

21. Bibu KJ, Joy AD, Mercey KA. Therapeutic effect of ethanolic extract of Hygrophila spinosa T Anders on gentamicin induced nephrotoxicity in rats. Int J Exp Bio. 2010;4:911-7.

22. Seale TW, Rennet OM. Mechanism of antibiotic induced nephrotoxicity. Aim Clin Lab Sci.1982;12:110

23. Gyselynck AM, Forrey A, Cutler R. Pharmacokinetics of gentamicin: Distribution and plasma renal clearance. J Infect Dis. 1971;124:P70-6.

24. Delanghe JR, Speeckaert MM. Creatinine determination according to Jaffe. What does it stand for NDT Plus. 2011;4(2):83-6. 
25. Mingeot-Leclercq MP, Glupczynsky Y, Tulkens P. M. Aminoglycosides: activity and resistance. Antimicrob. Agents Chemother. 1999;43:727-37.
Cite this article as: Kalita B, Sharma M,

Vishwakarma P, Bhatt S, Saini M, Saxena KK.

Evaluation of nephroprotective and nephrocurative activity of Aegle marmelos on albino rats using experimental model. Int J Basic Clin Pharmacol 2017;6:1104-9. 